\title{
Breast Composition: Measurement and Clinical Use
}

\section{Ernest Usang Ekpoab, Peter Hoggc, Ralph Highnamd, Mark F. McEnteea}

Breast density is a measure of the extent of radiodense fibroglandular tissue in the breast. The risk of developing breast cancer and the risk of missing cancer at screening rise with higher breast density. In this paper, the historical background to breast density measurement is outlined and current evidence based practice is explained. The relevance of breast density knowledge to mammographic practice and image interpretation is considered in the light of clinical assessment and notification of mammographic breast density (MBD). The current work also discusses risk stratification for decisionmaking regarding screening frequency and better modalities for earlier detection of breast cancer in the dense breast. Automated volumetric approaches are explained while ultrasound, digital breast tomosynthesis, molecular breast imaging, and magnetic resonance imaging are introduced as valuable adjuncts to digital mammography for imaging the dense breast. The work concludes on the important note that screened women should be notified of their breast density, and such notification should be accompanied with clear and adequate information about breast density and cancer risk, strategies associated with lower MBD, as well as best screening intervals and pathways for women with dense breasts. Adoption of these strategies may be crucial to early detection and treatment of cancer and improving survival from the disease.

\section{Introduction}

Breast density is a measure of the extent of radiodense fibroglandular tissue in the breast. ${ }^{1}$ A metaanalysis of breast cancer risk factors indicates that the risk of breast cancer from high breast density is twice higher than other risk factors except family history of the disease in women $40-49$ years. ${ }^{1}$ However, it is still contentious whether density is an independent risk factor or merely stimulates other risk factors to cause cancer. Regardless of these contentions, studies have shown that high breast density is associated with a 4-6 fold increased risk of breast cancer, ${ }^{2-5}$ and that a $1 \%$ increase in breast density is associated with $2 \%$ increase in breast cancer risk. ${ }^{4}$

Dense breast tissue has been shown to offer more opportunities for breast cancer to develop, especially in younger women. ${ }^{3,6-8}$ Additionally, there is a genetic predisposition to breast density, ${ }^{9}, 10$ and other established risk factors for breast cancer such as hormonal agents, ${ }^{11,}{ }^{12}$ lifestyle, and reproductive characteristics are associated with high breast density. ${ }^{13-16}$ Importantly, breast density is a potentially modifiable risk factor for breast cancer, ${ }^{17,}{ }^{18}$ and lower density has been shown to be a prognostic factor for the effect of interventions on breast cancer risk. ${ }^{19}$ Some lifestyle parameters responsible for high breast density and breast cancer are controllable, ${ }^{20}$ and consumption of food 
species such as vegetables, vitamin $\mathrm{D}$, and calcium may have an ameliorative impact on the breast density and breast cancer risk. ${ }^{21,22}$

Breast density is also a significant factor in interval breast cancer (cancer detected within 12 months after a normal screening mammogram), accounting for about $50 \% .^{3,5}$ Women with dense breasts are 4.7 to 17.8 times at risk of interval breast cancer relative to those with non-dense breasts., ${ }^{33-25}$ Mammographic breast density also reduces mammographic sensitivity and limits earlier detection of breast cancer with 2-dimensional mammography through masking effects. ${ }^{23}, 26$ Therefore, it is increasingly important to assess breast density of women undergoing screening mammography and inform women of their density. Such breast density data can improve women's awareness of their risks of breast cancer and interval cancer, and the potential of cancer being missed in their mammograms. This will allow for shared decision-making between screened women and their physicians concerning strategies to reduce the associated risks and facilitate better decisions regarding screening. ${ }^{17,19,27}$

National level breast density information will enable breast cancer risk stratification, ${ }^{27,}{ }^{28}$ leading to selection of appropriate imaging pathways such as ultrasound, ${ }^{29},{ }^{30}$ digital breast tomosynthesis (DBT), ${ }^{31}$ and magnetic resonance imaging $(\mathrm{MRI})^{30}$ to improve cancer detection in the dense breast. Breast density data can also be used to select personalised and appropriate screening intervals for screened women, such as screening less often and with digital mammography only for lower risk, fatty breasts and more frequently with DBT and whole breast Ultrasound for the denser breast. Data on breast density will enable use of breast density as a marker for monitoring the effect of breast cancer prevention and control interventions. ${ }^{17,19}$

The relevance of breast density information in clinical decision-making for screened women underscores the need for methods of breast density assessment to be standardized, reliable, and reproducible, as this will support clinical decisions made from breast density assessment. In this paper we revisit breast morphological and radiographic anatomy. We also examine the link between breast density and breast cancer, and approaches that have been employed to categorize mammographic breast density before tackling clinical uses.

\section{Breast Composition and Radiographic appearances}

Breast consists of fibroglandular tissue and fat, and their relative concentration determines the radiographic appearance of the breast. ${ }^{3} \mathrm{X}$-ray attenuation is higher in fibroglandular tissue than fat; as a result, fibroglandular tissue appears radiopaque (white) and constitutes a dense area of the breast and fat appears radiolucent (black). ${ }^{3}$ The dense portion of the breast contains high concentration of epithelial and stromal cells and collagen. ${ }^{3,32,33}$ 
Dense breasts are highly radiosensitive due to the high proliferation of epithelial and stromal cells in such breasts. ${ }^{34}$ To reduce the potential effect of radiation on the breast, there is a need to optimise the imaging procedure. Optimisation is aimed at producing good quality images at acceptable radiation dose. $^{35}$ The key radiographic determinant of image quality and dose is the detective quantum efficiency of the detector and composition of the X-ray spectrum, which in turn depends on the target material, tube voltage $(\mathrm{kVp})$, and filtration. ${ }^{35}$ These technical parameters impact not only on the diagnostic value of the image, but also the appearance of breast density to the human visual system. ${ }^{36}$, ${ }^{37}$ This is worrisome in film-screen mammography where radiographers have to manually select these factors. ${ }^{37}$ With automatic exposure control (AEC), exposure parameters are selected according to the physical characteristics of the breast or compressed breast thickness. ${ }^{38}$ Therefore, the same target/filter/kVp is chosen for a given breast density. Spectral and breast thickness information also influence the accuracy of volumetric breast density assessment. ${ }^{39,40}$ Studies have shown that higher atomic number target/filter combinations such as Tungsten/Rhodium (W/Rh) and Tungsten/Silver (W/Ag) produce the optimum spectrum for imaging the dense breast, and improve visualization of the dense breasts and features of cancer at lower doses. ${ }^{41,42}$ Therefore, for systems that do not have functional AEC, manual selection of the filter that produces the optimum spectrum for a given breast density is encouraged. Alternatively, dense breasts could be imaged with digital breast tomosynthesis (DBT). The high detector quantum efficiency (DQE), fast read-out ability, and low noise levels of digital detectors used in DBT have enabled acquisition of good quality images at low doses in dense breasts. ${ }^{43}$ DBT produces pseudo-cross-sectional images that reduce tissue superimposition and synthetic (reconstructed) 2-dimensional (2D) images which can be used as substitute for standard 2D images of digital mammography. The combined use of 3D images of DBT and standard 2D images of digital mammography (DM) has been shown to improve diagnostic accuracy, ${ }^{44,45}$ but is associated with increased radiation dose. ${ }^{43}$ However, use of reconstructed 2D images as substitute for standard 2D images has been found to be associated with a $45 \%$ reduction in mean glandular dose. ${ }^{43,46}$

\section{Mechanisms linking breast density to breast cancer}

Two theories have been postulated to explain the mechanisms linking breast density and breast cancer. The first mechanism involves mitogen (a chemical substance that encourages a cell to commence cell division, triggering mitosis), ${ }^{47}$ and mutagen effects (a physical or chemical agent that changes the genetic material of an organism and thus increases the frequency of mutations above the natural background level). ${ }^{48}$ The second mechanism involves biological interaction among epithelial and stromal cells, collagen and the breast microenvironment. ${ }^{32,33}$

It has been shown that mitogenic followed by mutagenic activity are at least in part, responsible for high breast density and breast cancer, where individuals with both high breast density and breast cancer demonstrate similar mitogen ${ }^{47}$ and mutagen characteristics. ${ }^{48}$ It is well known that mitogens 
induce cell proliferation, primarily affecting epithelial and stromal cells leading to increased fibroglandular tissue and higher levels of breast density mostly in premenopausal women. ${ }^{47,} 49$ Concomitantly, this increased presence of proliferating cells is very sensitive to mutagens resulting in changes and potential errors in DNA replication and strand recombination. ${ }^{50}$ Examples of specific mitogens that are responsible for both high breast density and breast cancer are insulin-like growth factor 1 and prolactin. ${ }^{47,49}$ A mutagen of oxidative stress that has been shown to be associated with breast density and cancer is cytochrome P450 1A2 (CYP1A2). ${ }^{48}$

It has also been shown that breasts with high density and those with cancer exhibit similar biological characteristics such as increased concentration of epithelial and stromal cells and collagen. ${ }^{32,33,51}$ Epithelial cell proliferation is necessary for breast density increases, however since breast cancer primarily evolve from epithelial cells, increased numbers of epithelial cells in the dense breast increase the possibility of cancer. ${ }^{33}$ Stromal cells induce cancer by modulating epithelial cells through epidermal growth factor receptor, IGF-1, and TGF- $\beta .^{52}$ Stromal cells are also progenitors, of collagen and stromal matrix which promote mammary gland development and tumour invasion ${ }^{52-54}$ and since collagen is linked to IGF-1 quantities and tumour reorganization, ${ }^{53}$ there are increased opportunities for cell proliferation and transformation to cancer. Also, the extracellular matrix expresses increased concentration of proteoglycans (lumican and decorin) in stroma associated with high breast density and cancer. These proteoglycans bind growth factors and increase breast tissue stiffness implicated in breast cancer. ${ }^{51}$ Together these intercellular interactions in the breast microenvironment result in each cell type becoming more tensile and more rigid, generating mechanical forces that can increase breast density and cancer risk. ${ }^{51,55}$

Breast density is associated with established risk factors for breast cancer except age and body mass index. ${ }^{11,12}$ Genome-wide studies have shown that breast cancer susceptibility genetic variants such as 8q (rs13281615), RAD51L1 (rs10483813), LSP1 (rs3817198), TOX3 (rs3803662) and MAP3K1 (rs889312) and many more are associated with breast density measures. ${ }^{56-59}$ There is also evidence that hormone replacement therapy, ${ }^{11}$ alcohol intake, ${ }^{16}$ and reproductive factors such as early menarche, nulliparity, late first term birth, ${ }^{60}$ and reduced breastfeeding ( $<12$ months) are associated with higher breast density. ${ }^{61,62}$ Anthropometric factors such as high birth weight and lower prepubertal weight are associated with higher breast density. ${ }^{63}$ The data produced shows that breast density information can be used in combination with other risk factors for stratification of breast cancer risk. Barlow et al. ${ }^{27}$ have shown an improvement in breast cancer risk prediction model with addition of breast density data. 
An important characteristic of breast density is that it is reducible, ${ }^{64-69}$ and preliminary studies have shown that breast density may serve as a biomarker for the effect of preventive interventions on breast cancer risk. ${ }^{17}$ The first International Breast Cancer Intervention Study (IBIS) trial of Tamoxifen ${ }^{\mathrm{TM}}$ versus placebo showed that women in the Tamoxifen group who had a 10\% or greater reduction in breast density demonstrated a $63 \%$ reduction in breast cancer risk but those who experienced less than $10 \%$ breast density reduction showed no risk reduction. ${ }^{17} \mathrm{Li}$ et al. ${ }^{19}$ showed that women treated with tamoxifen who experienced a relative density reduction of more than $20 \%$ had a $50 \%$ reduced risk of death from breast cancer. Randomized control trials demonstrated changes in breast density with intake of low-fat high carbohydrate diet. ${ }^{70,71}$ Cross-sectional studies have shown calcium and vitamin $\mathrm{D},{ }^{72-76}$ and vegetables ${ }^{75,77}$ to be associated with lower breast density.

Breast density assessment will enable monitoring of the effect of interventions that mitigate breast density and breast cancer risk. Therefore, it could become the responsibility of radiographers and radiologists to inform screened women of their breast density status, and to advise patients of the implications of high breast density including, informing them of their elevated risk of developing breast cancer, and the increased potential of cancer being concealed in their mammograms if they are dense. It may also be important that patients are provided with adequate information on how regularly they may need to be screened and other imaging modalities that may improve visualization of the dense areas for features of cancer. It is also increasingly important that screened women with dense breasts are advised to avoid lifestyles such as alcohol intake and exogenous hormone use that have been shown to increase cancer risk in women with dense breast. Also, consumption of food species associated with lower breast density ${ }^{22,72,75,77}$ and physical activity ${ }^{78}$ is encouraged as these may mitigate their risk of developing breast cancer.

\section{The history of qualitative breast density classification}

Interest in breast density classification dates back to 1969 when Wolfe and colleagues observed that breast with prominent ducts was associated with breast cancer risk. They considered prominent ducts a desmoplastic reaction which precedes breast cancer development in most breasts. ${ }^{79}$ In 1976, they developed the Wolfe method of breast density classification based on the appearance of breast parenchyma and prominence of $\operatorname{ducts}^{80}: \mathrm{N} 1, \mathrm{P} 1, \mathrm{P} 2$, DY, and Qdy (Table 1). This system classifies N1, P1 as low-risk densities and P2, DY as high risk breast densities. ${ }^{81}$ More than 40 studies have assessed associations with Wolfe grade or percentage breast density and the majority reported 2- to 6fold increased risks for the highest compared with the lowest risk categories. ${ }^{82}$

Table 1: Summary of Wolfe, Boyd, and Tabăr breast density classifications

\begin{tabular}{l|l|l}
\hline Wolfe patterns & Boyd SCC & Tabăr patterns \\
\hline
\end{tabular}




\begin{tabular}{l|l|l}
\hline $\begin{array}{l}\text { N1: Completely fatty with a few } \\
\text { fibrous connective tissue }\end{array}$ & $0 \%$ : No dense tissue & $\begin{array}{l}\text { I: Symmetry of all components with } \\
\text { slightly greater fibrous tissue } \\
\text { II: Bulk of fat tissue }\end{array}$ \\
$\begin{array}{l}\text { P1: Fatty with prominent ducts } \\
\begin{array}{l}\text { P2: Higher concentration of } \\
\text { prominent triangular ducts in } \\
\text { the central portion }\end{array}\end{array}$ & $10-25 \%$ dense tissue & $\begin{array}{l}\text { III: More fat tissue with fibrous tissue } \\
\text { in the retroareolar region }\end{array}$ \\
$\begin{array}{l}\text { DY: Homogenous density with } \\
\text { few ductal prominence }\end{array}$ & $26-50 \%$ dense tissue \\
$\begin{array}{l}\text { Qdy: Breast with spongy texture } \\
\text { VI: Mainly nodular densities }\end{array}$ & $51-75 \%$ dense tissue & V: Predominantly fibroglandular \\
\hline
\end{tabular}

SCC: Six category classification

In 1980, Boyd and colleagues proposed a six category classification system and subjectively classifies mammographic breast density as percentages based on the relative proportions of dense tissue and fat. ${ }^{83}$ Boyd's categories range from absence of dense tissue to excess density (Table 1), and considers breast with density $>75 \%$ at risk of cancer. The method has shown strong positive association between breast density and cancer risk. ${ }^{84,85}$ The driver for Boyd's work, although still subjective, was to try and introduce a more quantitative approach than offered by Wolfe.

In 1997, Tabảr and colleagues argued that the breast density classification by Wolfe has limited application in clinical practice and proposed a five scale mammographic breast density classification system based on histologic-mammographic correlations and on the relative proportions of four breast components. ${ }^{86}$ The method categorizes mammographic density into five parenchymal patterns (Table 1), with I, II and III considered as low-risk and IV and V as high-risk patterns. ${ }^{81,86}$ The method has shown strong positive association with breast cancer risk. ${ }^{81}$

In 2000, the American College of Radiology (ACR) modified and simplified the Wolfe and Boyd methods and proposed the breast imaging reporting and data systems (BIRADS) scheme. In 2003, the ACR updated BIRADS to the $4^{\text {th }}$ edition using Boyd method to propose a quantitative breast density classification based on the percentage of fibroglandular tissue in the breast. This scheme was last updated to the $5^{\text {th }}$ edition in $2013,{ }^{87}$ and subjectively classifies mammographic breast density based on the relative appearance of dense tissue and fat into four categories (A - D) (Figures 1 and 2). In the $5^{\text {th }}$ edition emphasis is on classification based on the potential for masking the risk of breast cancer. For example, breasts having $>50 \%$ fatty tissue, but with very dense tissue posterior to the nipple may be classified as category $\mathrm{C}$ or D. ${ }^{88}$ BIRADS is almost universally accepted and widely used qualitative methodology, and encourages users to describe the implications of the assigned breast density category, and areas on the mammogram where cancer is likely to be missed ${ }^{87}$ For example, it encourages users to inform patients that small lesions may be missed in BIRADS $\mathrm{C}$ and that 
mammography sensitivity is lower in category $\mathrm{D} .{ }^{89}$ Previous editions of BIRADS have demonstrated consistent association between breast density and cancer risk particularly in postmenopausal women. ${ }^{28,82}$ However, BIRADS suffers from reduced reproducibility and has shown wide inter-reader agreement $(\kappa)$ ranging from $0.37-0.91 .^{90-92}$ Therefore, an assessment of the extent of inter-reader agreement with the $5^{\text {th }}$ edition is increasingly relevant.

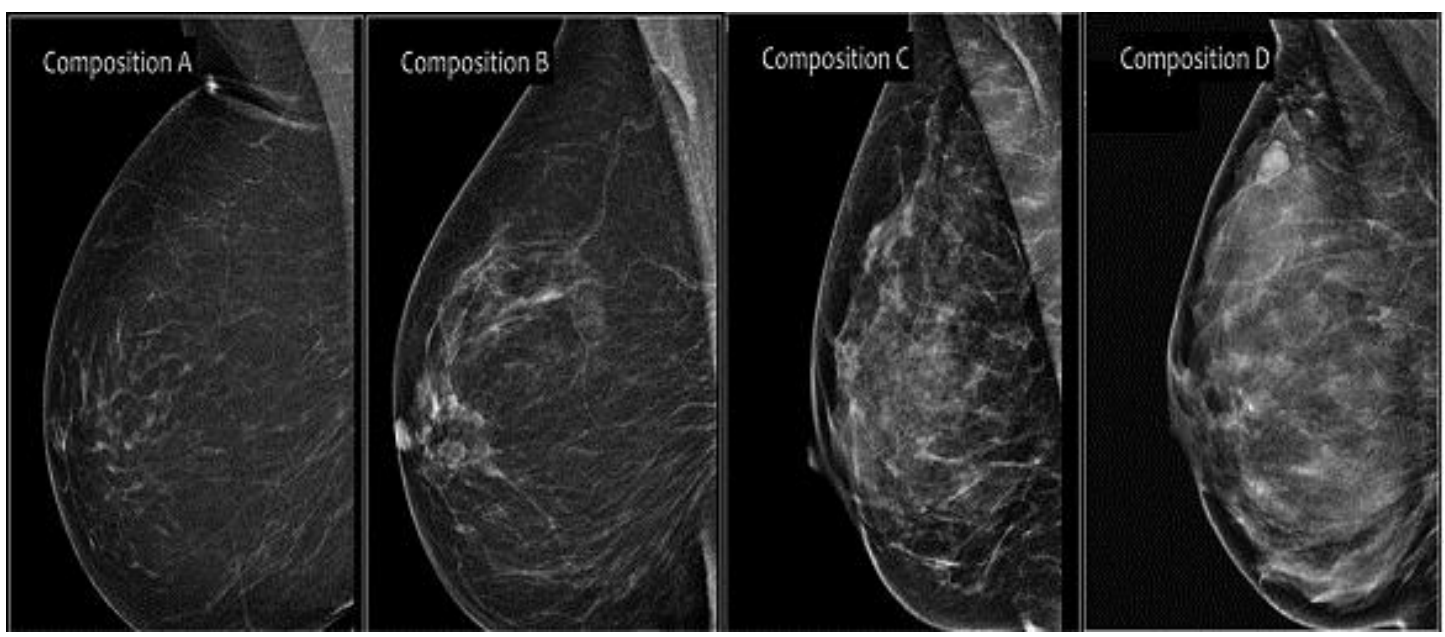

Figure 1: Breast imaging reporting and data systems $\left(5^{\text {th }}\right.$ edition) categories $\mathrm{A}-\mathrm{D}$. Note higher amount of dense tissue (white areas) in C and D (Labelled for reuse)

Table 2: Breast imaging reporting and data systems classification scheme in the $4^{\text {th }}$ and $5^{\text {th }}$ editions

\begin{tabular}{|c|c|c|c|}
\hline \multicolumn{2}{|r|}{$4^{\text {th }}$ Edition } & \multicolumn{2}{|r|}{$5^{\text {th }}$ Edition } \\
\hline 1 & $\begin{array}{l}\text { The breast is almost entirely fat }(<25 \% \\
\text { glandular) }\end{array}$ & $\mathbf{a}$ & The breasts are almost entirely fatty \\
\hline 2 & $\begin{array}{l}\text { There are scattered areas of fibroglandular } \\
\text { densities (approximately } 25-50 \% \text { glandular) }\end{array}$ & $\mathbf{b}$ & $\begin{array}{l}\text { There are scattered areas of } \\
\text { fibroglandular density }\end{array}$ \\
\hline 3 & $\begin{array}{l}\text { The breast is heterogeneously dense, which } \\
\text { could obscure detection of small masses } \\
\text { (approximately } 51-75 \% \text { glandular) }\end{array}$ & $\mathbf{c}$ & $\begin{array}{l}\text { The breasts are heterogeneously dense, } \\
\text { which may obscure small masses }\end{array}$ \\
\hline 4 & $\begin{array}{l}\text { The breast is extremely dense. This may lower } \\
\text { the sensitivity of mammography (> } 75 \% \\
\text { glandular) }\end{array}$ & d & $\begin{array}{l}\text { The breasts are extremely dense, which } \\
\text { lowers the sensitivity of mammography }\end{array}$ \\
\hline
\end{tabular}

Table 2: Description of BIRADS classification in the $4^{\text {th }}$ and $5^{\text {th }}$ edition scheme (Labelled for reuse) 
Visual approaches have shown strong positive association between mammographic breast density and breast cancer risk. ${ }^{81,84,86}$ However, variation in image acquisition parameters ( $\mathrm{kVp}$ and $\mathrm{mAs}$ ) may cause variations in image appearance, perception of radiographic features and therefore mammographic breast density. ${ }^{93-96}$ Consequently, the subjectivity of visual approaches and variation in image quality may cause inter-reader variability in mammographic breast density assessment. Subjective variability will consistently lead to variability in cancer risk stratification and unnecessary difference in clinical decision-making from mammographic breast density assessment. These deficiencies may limit the use of mammographic breast density information as biomarker for monitoring the effect of breast cancer preventive interventions. ${ }^{97,} 98$ Consequently, quantitative methodologies have been designed for mammographic breast density assessment in the clinical setting.

\section{Categorisation of Breast Composition Using “Quantitative Area-Based” Techniques}

Quantitative area-based techniques for mammographic breast density include semi-automated interactive thresholding techniques such as Cumulus (University of Toronto, Canada) and Madena (University of Southern California, US) and automated techniques such as AutoDensity (University of Melbourne, Australia), Image J (National Institute of Health), and MedDensity (University of Genova, Italy). ${ }^{92}$

Interactive thresholding methods use segmentation and thresholding techniques to select two grey levels for percentage mammographic density calculation. ${ }^{99}$ The first of these separates the image of the breast from the background, and aggregation of the pixels over the intensity range gives the maximum intensity and provides a measure of breast area $\left(A_{B}\right)$. The second threshold outlines the dense tissue (excluding the pectorialis muscle), and sums the pixels in this area to calculate area of dense tissue $\left(A_{D}\right)$ (Figure 2). The software packages calculate percentage mammographic density (PMD) as the ratio of the dense tissue and the total breast area multiplied by $100 .{ }^{100}$

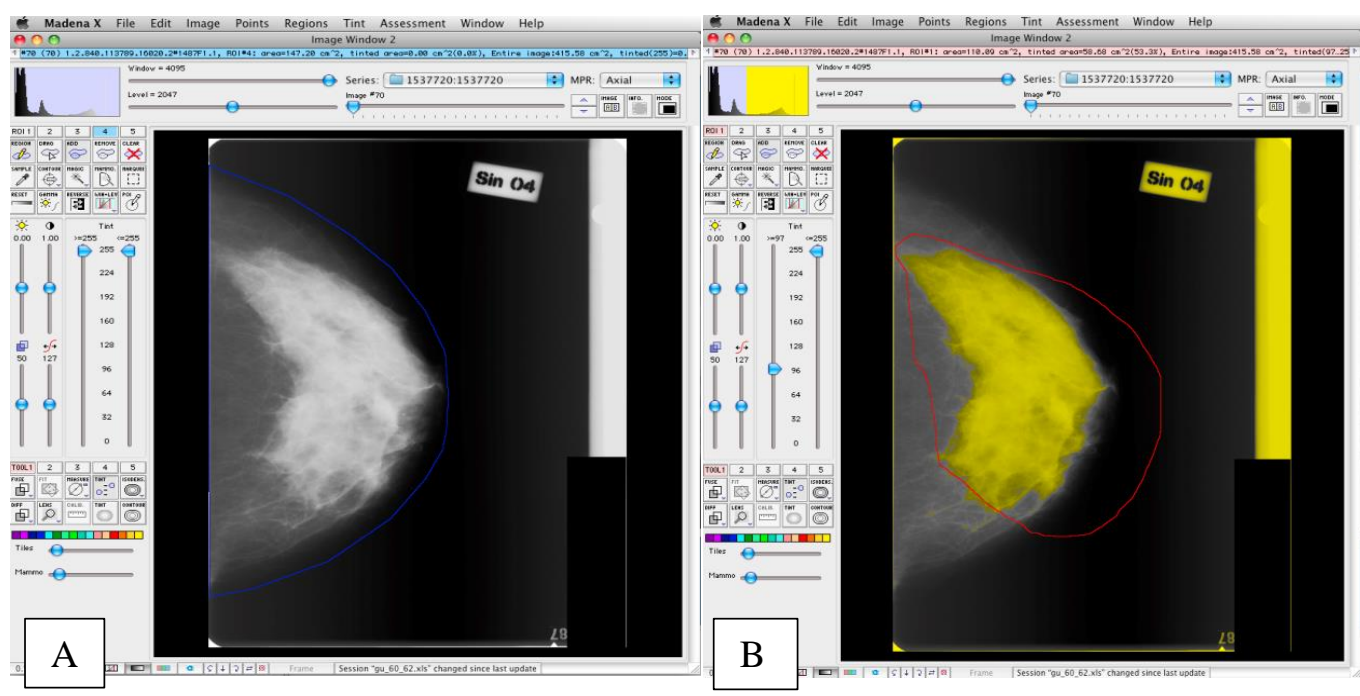


Figure 2: Example of Cumulus breast density assessment. (A) Cumulus interface, (B) thresholding taking place (Labelled for reuse).

Cumulus has demonstrated good association between breast density and cancer risk in multiple global studies. ${ }^{3,101,102}$ AutoDensity has been shown to be comparable to Cumulus for risk assessment ${ }^{24}$. MedDensity has been shown to demonstrate moderate correlation with BIRADS for breast density assessment. ${ }^{103-106}$ Image $\mathrm{J}$ has demonstrated strong correlation with Cumulus and BIRADS ${ }^{107}$ and positive association between breast density and cancer risk. ${ }^{28,108}$ However, quantum and anatomical noise reduce the reliability of AutoDensity and MedDensity. ${ }^{24,}{ }^{109}$ Image quality may limit accurate outlining of the dense area with semi-automated methods. ${ }^{110}$ Although semi-automated thresholding methods have better reproducibility than visual approaches, they are labour-intensive, timeconsuming, and still demonstrate intra- and inter-user variability. ${ }^{3,111-114}$ Furthermore, area-based techniques measure percentage dense area and treat the breast as a two-dimensional structure, ignoring the three-dimensional features of the breast. ${ }^{115}$

There are doubts that area measurement of breast density as percentage mammographic density (PMD) may not accurately reflect the quantity of dense tissue in the breast. ${ }^{115}$ This is because the quantity of dense tissue may vary in different breasts with the same dense area, and measured PMD of the same dense area may vary with variation in breast size (Figure 3). Therefore, area-based techniques may not be able to show change in breast density following intervention. ${ }^{97,}{ }^{98}$ These limitations have necessitated the introduction of volumetric methodologies for mammographic breast density assessment.

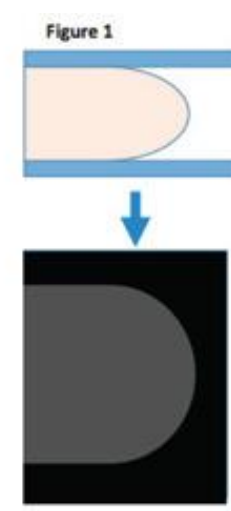

VISUAL: VOLUMETRIC:

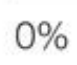

$0 \%$

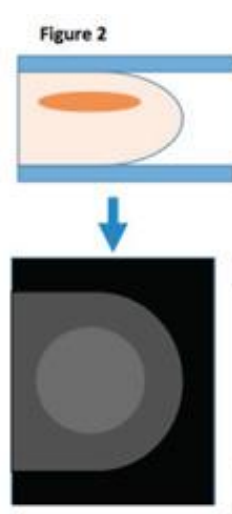

$50 \%$

$12 \%$

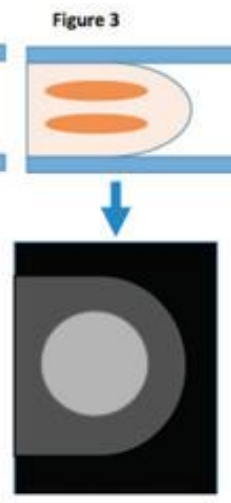

$50 \%$

$24 \%$
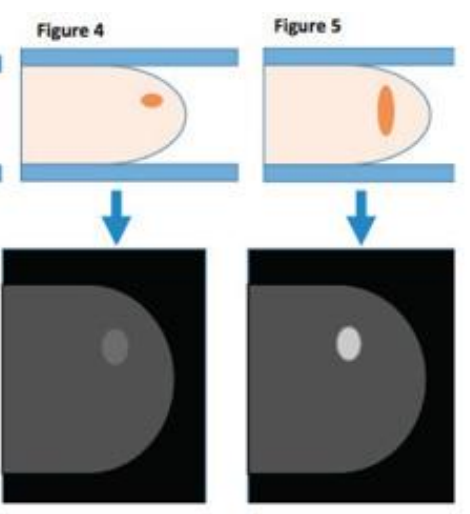

$5 \%$ $5 \%$ $5 \%$ $12 \%$

Figure 3: Illustration of how breast density can be under- or over-estimated by visual/area-based approaches. The second and third images show how dense area of different thicknesses given the 
same score by visual/area-based approaches and different scores by volumetric techniques (Reproduced with permission)

\section{Categorisation of Breast Composition Using Automated, Volumetric Techniques}

Volumetric techniques employ physics principles to volumetric breast density. Commercially available volumetric techniques include Quantra $^{\mathrm{TM}}$, Volpara ${ }^{\mathrm{TM}}$, and academic versions include CumulusV and Dual-energy X-ray absorptiometry. ${ }^{92,}{ }^{110}$ The commercial products come as networked/server-based software packages and are installed between the acquisition and display systems. They perform volumetric breast density assessment without any human intervention and send their output to the radiologist or technologist workstation where the results can be viewed immediately after image acquisition (Figure $4 \mathrm{~A} \& \mathrm{~B}$ ).

Quantra $^{\mathrm{TM}}$ (Hologic Inc.) uses a physical physics principle to calculate volumetric breast density. Volumetric breast density assessment is based on data related to the physical composition of the breast, compressed breast thickness, and the X-ray spectra (tube potential $(\mathrm{kVp})$, tube current (mAs), and filter type and thickness). ${ }^{39,40}$ Quantra estimates the thickness of the dense tissue above each pixel in the mammographic image and combines these pixel values to compute the total volume of the dense tissue in the breast $\left(\operatorname{Vfg}\left(\mathrm{cm}^{3}\right)\right) .{ }^{116}$ It aggregates the pixel values over the whole breast to calculate the volume of the breast, and then calculates percentage volumetric breast density (Vbd\%) as a percentage of the dense tissue volume and the total breast volume. The software calculates the breast density make-up of the patient by segmenting the Vbd\% into a total Quantized breast density (Q_abd) value. These Q_abd values range from $1-4$ and used to map the ACR BIRADS breast density categories (Figure 4B). Quantra has been shown to be an reliable ${ }^{117,118}$ and reproducible ${ }^{119,120}$ for mammographic breast density assessment, and a strong predictor of breast cancer risk from breast density. ${ }^{28}$ Quantra has also been shown to accurately reproduce radiologists' BIRADS assessment on a two-category scale. ${ }^{121,122}$

Volpara $^{\mathrm{TM}}$ (Matakina Technology Limited) is also based on relative physics principles, and measures mammographic breast density by finding a reference point of entirely fat $\left(\mathrm{P}_{\mathrm{FAT}}\right)$ in each image and then estimating X-ray attenuation relative to that point for all other points in the image. ${ }^{123}$ Volpara calculates volume of dense tissue by integrating the thickness of dense tissue at each pixel level values over the image; it then computes the volume of the breast by multiplying the area of the breast by the recorded breast thickness. ${ }^{124}$ It calculates percentage volumetric breast density as a percentage ratio of the volume of fibroglandular and the total volume of the breast. The software generates four volumetric density grades (VDGA - D) corresponding to the four ACR BIRADS breast density categories (Figure 4A). ${ }^{123-125}$ Volpara has demonstrated a strong positive correlation with BIRADS, ${ }^{124}$, 
${ }^{126}$ and has been shown to be more reliable and reproducible, ${ }^{39,117,118}$ and a better risk predictor from breast density assessment ${ }^{28}$ than other mammographic breast density assessment tools.

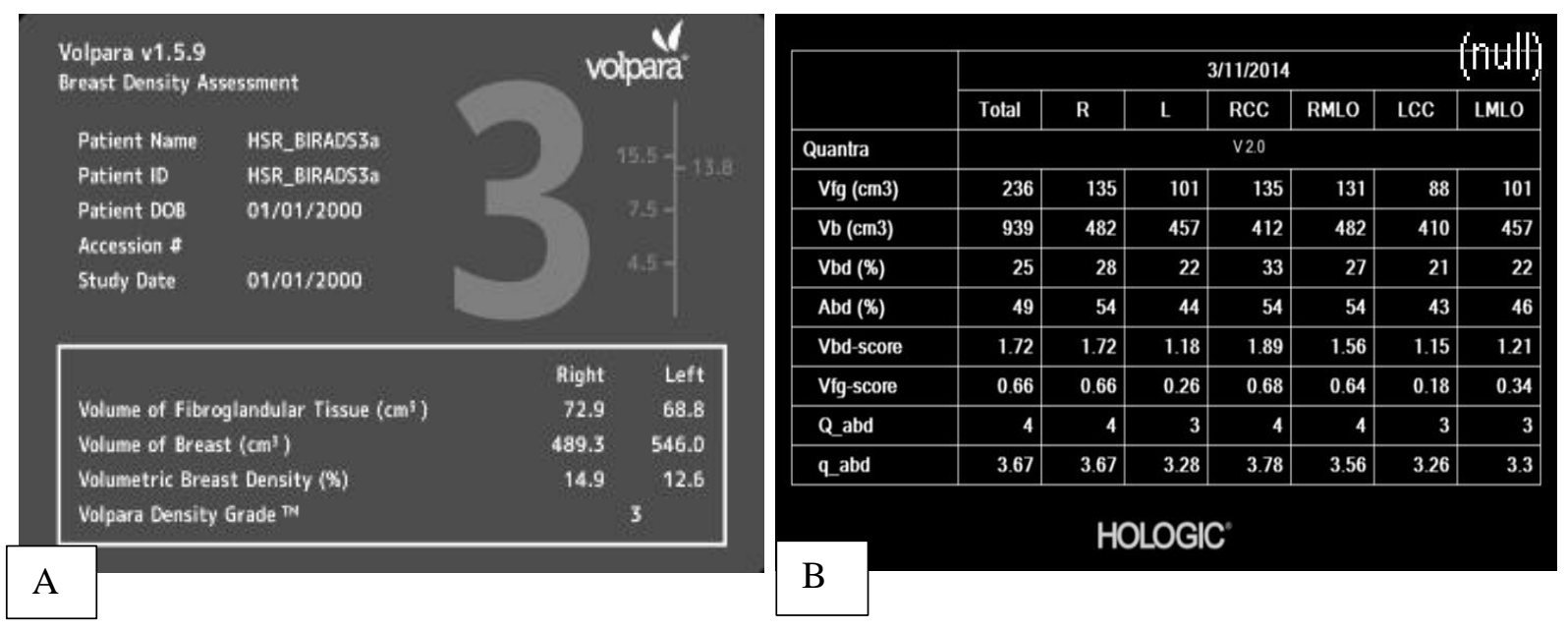

Figure 4: Display of assessed volumetric breast density results: In A,the Volpara Density grade is 3, and in B, Quantra the breast density grade (total Q_abd) is 4.

Currently, there is increased advocacy for breast density notification in the United States, ${ }^{127}$ and 22 states have already passed laws mandating disclosure of breast density information to screened women. ${ }^{128}$ Given the increased advocacy and legislation for breast density notification, it is worthwhile to employ tools that are robust enough for clinical use and devoid of subjectivity for mammographic breast density assessment. Interestingly, Volpara ${ }^{\mathrm{TM}}$ and Quantra ${ }^{\mathrm{TM}}$ are robust and provide breast density score to the practitioner within 2 minutes after the mammographic procedure. Their reliability and reproducibility as well as the ready availability of their results will allow for consistency and timely utilization of breast density information in clinical decision-making. Where these software packages are available, radiologists and technologists only have to review the breast density information generated by the software and provide a statement on the patient report about her breast density. It should however be noted that Volpara ${ }^{\mathrm{TM}}$ and Quantra $^{\mathrm{TM}}$ are used as adjuncts to radiologist assessment, and although shown now to correlate to sensitivity, ${ }^{129}$ they may not account for all the potential masking effects of breast density. Therefore, it is the responsibility of the image interpreter to accept or override the breast density report generated by the software based on their perceived masking effect.

\section{Radiographic Factors that can impact on Breast density measurement}

Volumetric methods rely on image acquisition parameters and compressed breast thickness to estimate volumetric breast density. It has been shown that when compression is applied with a flexible compression paddle, the upper plate may be tilted. Paddle tilt causes a variation in breast thickness from the thoracic wall to the breast edges, ${ }^{130,131}$ and results in a smooth intensity inhomogeneity field 
that distorts the image, limiting computerized image analysis. ${ }^{132,133}$ This is most often seen in fatty breasts where it creates a region of intensity inhomogeneity which is usually misinterpreted as a dense tissue component, leading to overestimation of a woman's breast density. ${ }^{134}$ The effect of the paddle tilt in dense breasts may be indeterminate. ${ }^{134}$ Positioning has been shown to cause density variation in digital mammography and digital breast tomosynthesis, ${ }^{109}$ and implants can be treated as a component of the breast by these volumetric techniques and cause errors in mammographic breast density estimation if the images are not tagged appropriately in the DICOM headers. ${ }^{135}$ Quantum noise influences the appearance of breast parenchyma in mammograms and determines that amount of fibroglandular tissues which can be quantified as volumetric breast density. This has been shown to reduce volumetric breast density estimated from mammograms. ${ }^{136}$ The foregoing demonstrate that factors under the radiographer's control may influence the accurate assessment of breast density with both visual and quantitative approaches, and emphasizes the need for correct technical parameters and procedures to be used for breast imaging. Additionally, quality assurance is very important to produce mammograms with normalized breast density value scale in order to overcome errors which may arise from variation in the technical parameters used for different breast compositions. ${ }^{137}$ Failure of calibration may cause poor dose control and strange density reports for breast thicknesses which are $2 \mathrm{~cm}$ greater than actual thickness. Mammograms with uncalibrated information may lead to errors in mammographic breast density assessment. ${ }^{138}$

\section{Imaging the dense breast}

The literature demonstrates that mammography suffers reduced sensitivity in dense breasts due to masking effect on high breast density, ${ }^{139}$ although it does appear to be very good for women with fatty breasts. Therefore, women with dense breasts who are elevated risk of breast cancer may benefit from adjunctive screening. Given that $31 \%-43 \%$ of screened women have high breast density, ${ }^{82}$ it is increasingly important to image dense breasts with appropriate imaging modalities to enhance visualization of the breast for cancer features. Also, since $50 \%$ of interval breast cancer is attributed to high mammographic breast density, ${ }^{3}$ it is essential to assess breast density of screened women in order to identify women who may need to be screened more regularly. Existing evidence shows that ultrasound, ${ }^{29,30}$ digital breast tomosynthesis, ${ }^{31}$ or MRI ${ }^{30}$ improves cancer detection in dense breasts although it remains unclear which one suits which breasts best.

Clinical trials have shown that supplemental screening breast ultrasound significantly improves detection of node-negative breast cancer in dense breasts. The reported diagnostic yield of supplemental breast ultrasound ranged from 3.5 - 14.6 per 1000 women. ${ }^{29,}{ }^{30,140-145}$ Ultrasound has $^{1}$ been shown to be particularly useful for detection of non-palpable lesions, ${ }^{145}$ invasive cancer ranging from 5 - 40mm in size, ${ }^{29,}{ }^{30}$ as well as mammographically occult cystic malignant lesions in dense 
parenchyma. ${ }^{140,146}$ Therefore, ultrasound should be recommended as the first choice supplemental modality for dense patients.

The ability of digital breast tomosynthesis (DBT) to produce cross-sectional images removes superimposed tissues that may conceal breast cancer. ${ }^{147}$ Increasingly, the synthesis of 3-dimensional (3D) images from DBT and the use of combined 2D and 3D improve detection of breast cancer in mammographically dense breasts. ${ }^{148,}{ }^{149}$ Studies have reported $7.2 \%-53 \%$ increase in cancer detection and 20\% - 59\% reduction in recall rates with supplemental DBT. ${ }^{31,44,45,150,151}$ Importantly, radiation dose to the dense tissue is lower for DBT than digital mammography (DM) for dense breasts; ${ }^{43}$ therefore DBT is preferable to DM in terms of performance and dose, albeit it appears women with fatty breasts get higher dose on DBT. ${ }^{152}$

Another approach suitable for imaging the dense breast is molecular breast imaging (MBI) or BreastSpecific Gamma Imaging (BSGI). This modality allows for use of probes as biomarkers to image particular targets or pathways. Studies have shown an improvement in breast cancer detection in dense breast, with cancer detection rate per 1000 women increasing from 3.2 for mammography alone to $12.0 \%$ with supplemental MBI. ${ }^{153}$ A review of the literature shows sensitivity ranging from $91 \%$ $96 \%$, with specificity of $60 \%-77 \%$ for MBI alone, ${ }^{154}$ and meta-analysis of published literature reported $95 \%$ sensitivity and $80 \%$ specificity. ${ }^{155}$ A major limitation of MBI is its high radiation dose which has the potential to cause mutation to the rapidly dividing cells in dense breasts. ${ }^{156}$ Work is underway to lower the dose.

Magnetic resonance imaging (MRI) is used as an adjunct to mammography, and has demonstrated high sensitivity and specificity. ${ }^{157}$ In addition to slice-by-slice evaluation of the breast parenchyma, MRI offers high resolution required for lesion identification and characterization. Studies have shown that the sensitivity of MRI for breast cancer detection range from $91 \%-100 \% .^{158-161}$ Supplemental MRI has been shown to improve diagnostic yield by $18.2 \%$ per 1000 women. ${ }^{159}$ Importantly, MRI is very accurate in excluding the risk of tumour recurrence, with enhancement indicating risk of tumour recurrence and vice-versa. ${ }^{162-164}$ MRI has been shown to be the most accurate imaging modality for examination of the dense breast. ${ }^{161}$ Therefore breast density assessment is important for radiographers and radiologists advise women with dense breasts of the most suitable imaging modality and screening interval so that cancer is detected early. ${ }^{165}$

\section{Conclusion}

High breast density is a significant determinant of breast cancer risk, mammographic sensitivity, and interval breast cancer. Breast density is associated with established risk factors for breast cancer 
related to genetics and lifestyle parameters. Importantly, breast density can be reduced by interventions such as Tamoxifene and low-fat high carbohydrate diet. Therefore, clinical assessment and notification of mammographic breast density (MBD) is relevant for the purpose of risk stratification, decision-making regarding screening frequency, and for tailoring women's imaging pathways to facilitate earlier detection of breast cancer. Mammographic breast density assessment will also enable monitoring of the effect of interventions on breast density and therefore breast cancer risk. Automated volumetric approaches are more preferable for MBD assessment, and ultrasound, digital breast tomosynthesis, molecular breast imaging, and magnetic resonance imaging are valuable adjuncts to digital mammography for imaging the dense breast. It is therefore increasingly relevant that screened women are notified of their breast density, and such notification accompanied with clear and adequate information about breast density and cancer risk, strategies associated with lower MBD, as well as best screening intervals and pathways for women with dense breasts. Adoption of these strategies may be crucial to breast cancer risk reduction, early detection and treatment of cancer, and improving survival from the disease.

Table 2: Breast imaging reporting and data systems classification scheme in the $4^{\text {th }}$ and $5^{\text {th }}$ editions

\begin{tabular}{|c|c|c|c|}
\hline \multicolumn{2}{|r|}{$4^{\text {th }}$ Edition } & \multicolumn{2}{|r|}{$5^{\text {th }}$ Edition } \\
\hline 1 & $\begin{array}{l}\text { The breast is almost entirely fat }(<25 \% \\
\text { glandular) }\end{array}$ & $\mathbf{a}$ & The breasts are almost entirely fatty \\
\hline 2 & $\begin{array}{l}\text { There are scattered areas of fibroglandular } \\
\text { densities (approximately 25-50\% glandular) }\end{array}$ & b & $\begin{array}{l}\text { There are scattered areas of } \\
\text { fibroglandular density }\end{array}$ \\
\hline 3 & $\begin{array}{l}\text { The breast is heterogeneously dense, which } \\
\text { could obscure detection of small masses } \\
\text { (approximately } 51-75 \% \text { glandular) }\end{array}$ & c & $\begin{array}{l}\text { The breasts are heterogeneously dense, } \\
\text { which may obscure small masses }\end{array}$ \\
\hline 4 & $\begin{array}{l}\text { The breast is extremely dense. This may lower } \\
\text { the sensitivity of mammography }(>75 \% \\
\text { glandular) }\end{array}$ & d & $\begin{array}{l}\text { The breasts are extremely dense, } \\
\text { which lowers the sensitivity of } \\
\text { mammography }\end{array}$ \\
\hline
\end{tabular}

Table 1: Summary of Wolfe, Boyd, and Tabăr breast density classifications

\begin{tabular}{|c|c|c|}
\hline Wolfe patterns & Boyd SCC & Tabăr patterns \\
\hline $\begin{array}{l}\text { N1: Completely fatty with a few } \\
\text { fibrous connective tissue }\end{array}$ & $0 \%:$ No dense tissue & $\begin{array}{l}\text { I: Symmetry of all components with } \\
\text { slightly greater fibrous tissue }\end{array}$ \\
\hline $\begin{array}{l}\text { P1: Fatty with prominent ducts } \\
\leq 4 \mathrm{~mm} \text { in diameter }\end{array}$ & $<10 \%$ dense tissue & II: Bulk of fat tissue \\
\hline $\begin{array}{l}\text { P2: Higher concentration of } \\
\text { prominent triangular ducts in } \\
\text { the central portion }\end{array}$ & $10-25 \%$ dense tissue & $\begin{array}{l}\text { III: More fat tissue with fibrous tissue } \\
\text { in the retroareolar region }\end{array}$ \\
\hline $\begin{array}{l}\text { DY: Homogenous density with } \\
\text { few ductal prominence }\end{array}$ & $26-50 \%$ dense tissue & VI: Mainly nodular densities \\
\hline \multirow[t]{2}{*}{ Qdy: Breast with spongy texture } & $51-75 \%$ dense tissue & V: Predominantly fibroglandular \\
\hline & $>75 \%$ : Extremely dense & \\
\hline
\end{tabular}




\section{References}

1. Nelson HD, Zakher B, Cantor A, Fu R, Griffin J, O'Meara ES, et al. Risk factors for breast cancer for women aged 40 to 49 years: a systematic review and meta-analysis. Ann Intern Med. 2012;156:635-48.

2. Boyd NF, Lockwood GA, Martin LJ, Knight JA, Byng JW, Yaffe MJ, et al. Mammographic densities and breast cancer risk. Breast disease. 1998;10:113-26.

3. Boyd NF, Guo H, Martin LJ, Sun L, Stone J, Fishell E, et al. Mammographic density and the risk and detection of breast cancer. N Engl J Med. 2007;356:227-36.

4. Boyd NF, Martin LJ, Bronskill M, Yaffe MJ, Duric N, Minkin S. Breast tissue composition and susceptibility to breast cancer. J Natl Cancer Inst. 2010;102:1224-37.

5. Boyd NF. Mammographic density and risk of breast cancer. American Society of Clinical Oncology educational book / ASCO American Society of Clinical Oncology Meeting. 2013.

6. Cecchini RS, Costantino JP, Cauley JA, Cronin WM, Wickerham DL, Bandos H, et al. Baseline mammographic breast density and the risk of invasive breast cancer in postmenopausal women participating in the NSABP study of tamoxifen and raloxifene (STAR). Cancer Prev Res (Phila Pa). 2012;5:1321-9.

7. Chiu SYH, Duffy S, Yen AMF, Tabar L, Smith RA, Chen HH. Effect of Baseline Breast Density on Breast Cancer Incidence, Stage, Mortality, and Screening Parameters: 25-Year Follow-up of a Swedish Mammographic Screening. Cancer Epidemiology Biomarkers \& Prevention. 2010;19:121928.

8. Duffy SW, Nagtegaal ID, Astley SM, Gillan MG, McGee MA, Boggis CR, et al. Visually assessed breast density, breast cancer risk and the importance of the craniocaudal view. Breast Cancer Res. 2008;10:R64.

9. Boyd NF, Dite GS, Stone J, Gunasekara A, English DR, McCredie MR, et al. Heritability of mammographic density, a risk factor for breast cancer. N Engl J Med. 2002;347:886-94.

10. Boyd NF, Martin LJ, Rommens JM, Paterson AD, Minkin S, Yaffe MJ, et al. Mammographic density: a heritable risk factor for breast cancer. Methods Mol Biol. 2009;472:343-60.

11. Carmona Sanchez E, Cuadros Lopez JL, Cuadros Celorrio AM, Perez-Roncero G, Gonzalez Ramirez AR, Fernandez Alonso AM. Assessment of mammographic density in postmenopausal women during long term hormone replacement therapy. Gynecol Endocrinol. 2013.

12. Couto E, Qureshi SA, Hofvind S, Hilsen M, Aase H, Skaane P, et al. Hormone therapy use and mammographic density in postmenopausal Norwegian women. Breast Cancer Res Treat. 2012;132:297-305.

13. Butler LM, Gold EB, Greendale GA, Crandall CJ, Modugno F, Oestreicher N, et al. Menstrual and reproductive factors in relation to mammographic density: the Study of Women's Health Across the Nation (SWAN). Breast Cancer Res Treat. 2008;112:165-74.

14. Conroy SM, Koga K, Woolcott CG, Dahl T, Byrne C, Nagata C, et al. Higher alcohol intake may modify the association between mammographic density and breast cancer: an analysis of three casecontrol studies. Cancer epidemiol. 2012;36:458-60.

15. Woolcott CG, Koga K, Conroy SM, Byrne C, Nagata C, Ursin G, et al. Mammographic density, parity and age at first birth, and risk of breast cancer: an analysis of four case-control studies. Breast Cancer Res Treat. 2012;132:1163-71.

16. Cabanes A, Pastor-Barriuso R, Garcia-Lopez M, Pedraz-Pingarron C, Sanchez-Contador C, Vazquez Carrete JA, et al. Alcohol, tobacco, and mammographic density: a population-based study. Breast Cancer Res Treat. 2011;129:135-47.

17. Cuzick J, Warwick J, Pinney E, Duffy SW, Cawthorn S, Howell A, et al. Tamoxifen-induced reduction in mammographic density and breast cancer risk reduction: a nested case-control study. $\mathbf{J}$ Natl Cancer Inst. 2011;103:744-52.

18. Cuzick J, Warwick J, Pinney E, Warren RM, Duffy SW. Tamoxifen and breast density in women at increased risk of breast cancer. J Natl Cancer Inst. 2004;96:621-8.

19. Li J, Humphreys K, Eriksson L, Edgren G, Czene K, Hall P. Mammographic density reduction is a prognostic marker of response to adjuvant tamoxifen therapy in postmenopausal patients with breast cancer. J Clin Oncol. 2013;31:2249-56. 
20. Parkin DM, Boyd L, Walker LC. 16. The fraction of cancer attributable to lifestyle and environmental factors in the UK in 2010. Br J Cancer. 2011;105 Suppl 2:S77-81.

21. Lindgren J, Dorgan J, Savage-Williams J, Coffman D, Hartman T. Diet across the Lifespan and the Association with Breast Density in Adulthood. International journal of breast cancer. 2013;2013:808317.

22. Cui Y, Rohan TE. Vitamin D, calcium, and breast cancer risk: a review. Cancer Epidemiol Biomarkers Prev. 2006;15:1427-37.

23. Mandelson MT, Oestreicher N, Porter PL, White D, Finder CA, Taplin SH, et al. Breast density as a predictor of mammographic detection: comparison of interval- and screen-detected cancers. $\mathrm{J}$ Natl Cancer Inst. 2000;92:1081-7.

24. Nickson C, Arzhaeva Y, Aitken Z, Elgindy T, Buckley M, Li M, et al. AutoDensity: an automated method to measure mammographic breast density that predicts breast cancer risk and screening outcomes. Breast Cancer Res. 2013;15:R80.

25. Pollan M, Ascunce N, Ederra M, Murillo A, Erdozain N, Ales-Martinez J, et al. Mammographic density and risk of breast cancer according to tumor characteristics and mode of detection: a Spanish population-based case-control study. Breast Cancer Res. 2013;15:R9.

26. Al-Mousa DS, Ryan EA, Mello-Thoms C, Brennan PC. What effect does mammographic breast density have on lesion detection in digital mammography? Clin Radiol. 2014;69:333-41.

27. Barlow WE, White E, Ballard-Barbash R, Vacek PM, Titus-Ernstoff L, Carney PA, et al. Prospective breast cancer risk prediction model for women undergoing screening mammography. $\mathrm{J}$ Natl Cancer Inst. 2006;98:1204-14.

28. Eng A, Gallant Z, Shepherd J, McCormack V, Li J, Dowsett M, et al. Digital mammographic density and breast cancer risk: a case inverted question markcontrol study of six alternative density assessment methods. Breast Cancer Res. 2014;16:439.

29. Berg WA, Blume JD, Cormack JB, Mendelson EB, Lehrer D, Bohm-Velez M, et al. Combined screening with ultrasound and mammography vs mammography alone in women at elevated risk of breast cancer. Jama. 2008;299:2151-63.

30. Berg WA, Zhang Z, Lehrer D, Jong RA, Pisano ED, Barr RG, et al. Detection of breast cancer with addition of annual screening ultrasound or a single screening MRI to mammography in women with elevated breast cancer risk. Jama. 2012;307:1394-404.

31. Rafferty EA, Park JM, Philpotts LE, Poplack SP, Sumkin JH, Halpern EF, et al. Assessing radiologist performance using combined digital mammography and breast tomosynthesis compared with digital mammography alone: results of a multicenter, multireader trial. Radiology. 2013;266:104-13.

32. Alowami S, Troup S, Al-Haddad S, Kirkpatrick I, Watson PH. Mammographic density is related to stroma and stromal proteoglycan expression. Breast Cancer Res. 2003;5:R129-35.

33. Hawes D, Downey S, Pearce CL, Bartow S, Wan P, Pike MC, et al. Dense breast stromal tissue shows greatly increased concentration of breast epithelium but no increase in its proliferative activity. Breast Cancer Res. 2006;8:R24.

34. Golubicic I, Borojevic N, Pavlovic T. Risk factors for breast cancer: is ionizing radiation among them? Journal of BUON : official journal of the Balkan Union of Oncology. 2008;13:487-94.

35. Ekpo EU, Hoban AC, McEntee MF. Optimisation of direct digital chest radiography using $\mathrm{Cu}$ filtration. Radiography. 2014;20:346-50.

36. Cherel P, Hagay C, Benaim B, De Maulmont C, Engerand S, Langer A, et al. Mammographic evaluation of dense breasts: techniques and limits. J Radiol. 2008;89:1156-68.

37. Jackson VP, Hendrick RE, Feig SA, Kopans DB. Imaging of the radiographically dense breast. Radiology. 1993;188:297-301.

38. Williams MB, Raghunathan P, More MJ, Seibert JA, Kwan A, Lo JY, et al. Optimization of exposure parameters in full field digital mammography. Med Phys. 2008;35:2414-23.

39. Highnam R, Brady M, Yaffe MJ, Karssemeijer N, Harvey J. Robust Breast Composition Measurement - Volpara (TM). In: Marti J, Oliver A, Freixenet J, Marti R, editors. Digital Mammography. Berlin: Springer-Verlag Berlin; 2010. p. 342-9.

40. Ren B, Smith A, Jing Z. Measurement of breast density with digital breast tomosynthesis. San Diego, CA2012. 
41. Baldelli P, Phelan N, Egan G. Investigation of the effect of anode/filter materials on the dose and image quality of a digital mammography system based on an amorphous selenium flat panel detector. Br J Radiol. 2010;83:290-5.

42. Bernhardt P, Mertelmeier T, Hoheisel M. X-ray spectrum optimization of full-field digital mammography: simulation and phantom study. Med Phys. 2006;33:4337-49.

43. Svahn TM, Houssami N, Sechopoulos I, Mattsson S. Review of radiation dose estimates in digital breast tomosynthesis relative to those in two-view full-field digital mammography. Breast. 2015;24:93-9.

44. Ciatto S, Houssami N, Bernardi D, Caumo F, Pellegrini M, Brunelli S, et al. Integration of 3D digital mammography with tomosynthesis for population breast-cancer screening (STORM): a prospective comparison study. Lancet Oncol. 2013;14:583-9.

45. Skaane P, Bandos AI, Gullien R, Eben EB, Ekseth U, Haakenaasen U, et al. Comparison of digital mammography alone and digital mammography plus tomosynthesis in a population-based screening program. Radiology. 2013;267:47-56.

46. Svahn T, Andersson I, Chakraborty D, Svensson S, Ikeda D, Fornvik D, et al. The diagnostic accuracy of dual-view digital mammography, single-view breast tomosynthesis and a dual-view combination of breast tomosynthesis and digital mammography in a free-response observer performance study. Radiation protection dosimetry. 2010;139:113-7.

47. Boyd NF, Stone J, Martin LJ, Jong R, Fishell E, Yaffe M, et al. The association of breast mitogens with mammographic densities. Br J Cancer. 2002;87:876-82.

48. Hong CC, Tang BK, Rao V, Agarwal S, Martin L, Tritchler D, et al. Cytochrome P450 1A2 (CYP1A2) activity, mammographic density, and oxidative stress: a cross-sectional study. Breast Cancer Res. 2004;6:R338-51.

49. Byrne C, Colditz GA, Willett WC, Speizer FE, Pollak M, Hankinson SE. Plasma insulin-like growth factor (IGF) I, IGF-binding protein 3, and mammographic density. Cancer Res. 2000;60:37448.

50. Yue W, Santen RJ, Wang JP, Li Y, Verderame MF, Bocchinfuso WP, et al. Genotoxic metabolites of estradiol in breast: potential mechanism of estradiol induced carcinogenesis. The Journal of steroid biochemistry and molecular biology. 2003;86:477-86.

51. Boyd NF, Li Q, Melnichouk O, Huszti E, Martin LJ, Gunasekara A, et al. Evidence that breast tissue stiffness is associated with risk of breast cancer. PLoS One. 2014;9:e100937.

52. Guo YP, Martin LJ, Hanna W, Banerjee D, Miller N, Fishell E, et al. Growth factors and stromal matrix proteins associated with mammographic densities. Cancer Epidemiol Biomarkers Prev. 2001;10:243-8.

53. Provenzano PP, Eliceiri KW, Campbell JM, Inman DR, White JG, Keely PJ. Collagen reorganization at the tumor-stromal interface facilitates local invasion. BMC medicine. 2006;4:38.

54. Provenzano PP, Inman DR, Eliceiri KW, Knittel JG, Yan L, Rueden CT, et al. Collagen density promotes mammary tumor initiation and progression. BMC medicine. 2008;6:11.

55. Butcher DT, Alliston T, Weaver VM. A tense situation: forcing tumour progression. Nat Rev Cancer. 2009;9:108-22.

56. Fernandez-Navarro P, Pita G, Santamarina C, Moreno MP, Vidal C, Miranda-Garcia J, et al. Association analysis between breast cancer genetic variants and mammographic density in a large population-based study (Determinants of Density in Mammographies in Spain) identifies susceptibility loci in TOX3 gene. European journal of cancer (Oxford, England : 1990). 2013;49:47481.

57. Easton DF, Pooley KA, Dunning AM, Pharoah PD, Thompson D, Ballinger DG, et al. Genomewide association study identifies novel breast cancer susceptibility loci. Nature. 2007;447:1087-93.

58. Odefrey F, Stone J, Gurrin LC, Byrnes GB, Apicella C, Dite GS, et al. Common genetic variants associated with breast cancer and mammographic density measures that predict disease. Cancer Res. 2010;70:1449-58.

59. Vachon CM, Scott CG, Fasching PA, Hall P, Tamimi RM, Li J, et al. Common breast cancer susceptibility variants in LSP1 and RAD51L1 are associated with mammographic density measures that predict breast cancer risk. Cancer Epidemiol Biomarkers Prev. 2012;21:1156-66. 
60. Ishihara S, Taira N, Kawasaki K, Ishibe Y, Mizoo T, Nishiyama K, et al. Association between mammographic breast density and lifestyle in Japanese women. Acta medica Okayama. 2013;67:14551.

61. Dai H, Yan Y, Wang P, Liu P, Cao Y, Xiong L, et al. Distribution of mammographic density and its influential factors among Chinese women. International journal of epidemiology. 2014.

62. Dorgan JF, Klifa C, Deshmukh S, Egleston BL, Shepherd JA, Kwiterovich PO, Jr., et al. Menstrual and reproductive characteristics and breast density in young women. Cancer Causes Control. 2013;24:1973-83.

63. Lope V, Perez-Gomez B, Moreno MP, Vidal C, Salas-Trejo D, Ascunce N, et al. Childhood factors associated with mammographic density in adult women. Breast Cancer Res Treat. 2011;130:965-74.

64. Decensi A, Robertson C, Guerrieri-Gonzaga A, Serrano D, Cazzaniga M, Mora S, et al. Randomized double-blind $2 \times 2$ trial of low-dose tamoxifen and fenretinide for breast cancer prevention in high-risk premenopausal women. J Clin Oncol. 2009;27:3749-56.

65. Atkinson C, Warren R, Bingham SA, Day NE. Mammographic patterns as a predictive biomarker of breast cancer risk: effect of tamoxifen. Cancer Epidemiol Biomarkers Prev. 1999;8:8636.

66. Chow CK, Venzon D, Jones EC, Premkumar A, O'Shaughnessy J, Zujewski J. Effect of tamoxifen on mammographic density. Cancer Epidemiol Biomarkers Prev. 2000;9:917-21.

67. Konez O, Goyal M, Reaven RE. Can tamoxifen cause a significant mammographic density change in breast parenchyma? Clin Imaging. 2001;25:303-8.

68. Meggiorini ML, Labi L, Vestri AR, Porfiri LM, Savelli S, De Felice C. Tamoxifen in women with breast cancer and mammographic density. Eur J Gynaecol Oncol. 2008;29:598-601.

69. Son HJ, Oh KK. Significance of follow-up mammography in estimating the effect of tamoxifen in breast cancer patients who have undergone surgery. AJR Am J Roentgenol. 1999;173:905-9.

70. Boyd NF, Greenberg C, Lockwood G, Little L, Martin L, Byng J, et al. Effects at two years of a low-fat, high-carbohydrate diet on radiologic features of the breast: results from a randomized trial. Canadian Diet and Breast Cancer Prevention Study Group. J Natl Cancer Inst. 1997;89:488-96.

71. Knight JA, Martin LJ, Greenberg CV, Lockwood GA, Byng JW, Yaffe MJ, et al. Macronutrient intake and change in mammographic density at menopause: Results from a randomized trial. Cancer Epidemiology Biomarkers \& Prevention. 1999;8:123-8.

72. Berube S, Diorio C, Masse B, Hebert-Croteau N, Byrne C, Cote G, et al. Vitamin D and calcium intakes from food or supplements and mammographic breast density. Cancer Epidemiol Biomarkers Prev. 2005;14:1653-9.

73. Berube S, Diorio C, Verhoek-Oftedahl W, Brisson J. Vitamin D, calcium, and mammographic breast densities. Cancer Epidemiol Biomarkers Prev. 2004;13:1466-72.

74. Diorio C, Berube S, Byrne C, Masse B, Hebert-Croteau N, Yaffe M, et al. Influence of insulinlike growth factors on the strength of the relation of vitamin $\mathrm{D}$ and calcium intakes to mammographic breast density. Cancer Res. 2006;66:588-97.

75. Masala G, Ambrogetti D, Assedi M, Giorgi D, Del Turco MR, Palli D. Dietary and lifestyle determinants of mammographic breast density. A longitudinal study in a Mediterranean population. Int J Cancer. 2006;118:1782-9.

76. Tseng M, Byrne C, Evers KA, Daly MB. Dietary intake and breast density in high-risk women: a cross-sectional study. Breast Cancer Res. 2007;9:R72.

77. Brisson J, Verreault R, Morrison AS, Tennina S, Meyer F. Diet, mammographic features of breast tissue, and breast cancer risk. Am J Epidemiol. 1989;130:14-24.

78. Friedenreich CM, Courneya KS, Bryant HE. Relation between intensity of physical activity and breast cancer risk reduction. Medicine and science in sports and exercise. 2001;33:1538-45.

79. Wolfe JN. The prominent duct pattern as an indicator of cancer risk. Oncology. 1969;23:149-58.

80. Wolfe JN. Risk for breast cancer development determined by mammographic parenchymal pattern. Cancer. 1976;37:2486-92.

81. Gram IT, Bremnes Y, Ursin G, Maskarinec G, Bjurstam N, Lund E. Percentage density, Wolfe's and Tabar's mammographic patterns: agreement and association with risk factors for breast cancer. Breast Cancer Res. 2005;7:R854-61. 
82. McCormack VA, dos Santos Silva I. Breast density and parenchymal patterns as markers of breast cancer risk: a meta-analysis. Cancer Epidemiol Biomarkers Prev. 2006;15:1159-69.

83. Boyd NF, Lockwood GA, Byng JW, Tritchler DL, Yaffe MJ. Mammographic densities and breast cancer risk. Cancer Epidemiol Biomarkers Prev. 1998;7:1133-44.

84. Boyd NF, Byng JW, Jong RA, Fishell EK, Little LE, Miller AB, et al. Quantitative classification of mammographic densities and breast cancer risk: results from the Canadian National Breast Screening Study. J Natl Cancer Inst. 1995;87:670-5.

85. Boyd NF, Jensen HM, Cooke G, Han HL, Lockwood GA, Miller AB. Mammographic densities and the prevalence and incidence of histological types of benign breast disease. Reference Pathologists of the Canadian National Breast Screening Study. Eur J Cancer Prev. 2000;9:15-24.

86. Gram IT, Funkhouser E, Tabar L. The Tabar classification of mammographic parenchymal patterns. Eur J Radiol. 1997;24:131-6.

87. ACR. Breast imaging reporting and data system (BIRADS). ACR BI-RADS® ATLAS MAMMOGRAPHY 5th ed. Reston, Va:: American College of Radiology; 2013.

88. Moan R. New BI-RADS uncouples assessment and management. European Congress of Radiology Austria Vienna2014.

89. BI-RADS 5th Edition ACR 5th ed. Reston VA: American College of Radiology; 2013.

90. Spayne MC, Gard CC, Skelly J, Miglioretti DL, Vacek PM, Geller BM. Reproducibility of BIRADS breast density measures among community radiologists: a prospective cohort study. Breast $\mathrm{J}$. 2012;18:326-33.

91. Bernardi D, Pellegrini M, Di Michele S, Tuttobene P, Fanto C, Valentini M, et al. Interobserver agreement in breast radiological density attribution according to BI-RADS quantitative classification. Radiologia Medica. 2012;117:519-28.

92. Ekpo EU, McEntee MF. Measurement of breast density with Digital Breast Tomosynthesis- a systematic review. Br J Radiol. 2014:20140460.

93. Saunders RS, Baker JA, Delong DM, Johnson JP, Samei E. Does image quality matter? Impact of resolution and noise on mammographic task performance. Med Phys. 2007;34:3971-81.

94. Rawashdeh MA, Lee WB, Bourne RM, Ryan EA, Pietrzyk MW, Reed WM, et al. Markers of good performance in mammography depend on number of annual readings. Radiology. 2013;269:617.

95. Bertram R, Helle L, Kaakinen JK, Svedstrom E. The effect of expertise on eye movement behaviour in medical image perception. PLoS One. 2013;8:e66169.

96. Kompaniez E, Abbey CK, Boone JM, Webster MA. Adaptation aftereffects in the perception of radiological images. PLoS One. 2013;8:e76175.

97. Eng-Wong J, Orzano-Birgani J, Chow CK, Venzon D, Yao J, Galbo CE, et al. Effect of raloxifene on mammographic density and breast magnetic resonance imaging in premenopausal women at increased risk for breast cancer. Cancer Epidemiol Biomarkers Prev. 2008;17:1696-701.

98. Shepherd JA, Kerlikowske KM, Smith-Bindman R, Genant HK, Cummings SR. Measurement of breast density with dual X-ray absorptiometry: Feasibility. Radiology. 2002;223:554-7.

99. Harvey JA, Bovbjerg VE. Quantitative assessment of mammographic breast density: relationship with breast cancer risk. Radiology. 2004;230:29-41.

100. Bakic PR, Kontos D, Zhang CP, Yaffe MJ, Maidment ADA. Analysis of percent density estimates from digital breast tomosynthesis projection images - art. no. 651424. In: Giger ML, Karssemeijer N, editors. Medical Imaging 2007: Computer-Aided Diagnosis, Pts 1 and 2. Bellingham: Spie-Int Soc Optical Engineering; 2007. p. 51424-.

101. Reed S, Ertas G, Doran S, Warren RM, Leach MO. Robustness of interactive intensity thresholding based breast density assessment in MR-Mammography. In: Karssemeijer N, Summers RM, editors. Medical Imaging 2010: Computer - Aided Diagnosis. Bellingham: Spie-Int Soc Optical Engineering; 2010.

102. Palomares MR, Machia JR, Lehman CD, Daling JR, McTiernan A. Mammographic density correlation with Gail model breast cancer risk estimates and component risk factors. Cancer Epidemiol Biomarkers Prev. 2006;15:1324-30.

103. Tagliafico A, Tagliafico G, Astengo D, Airaldi S, Calabrese M, Houssami N. Comparative estimation of percentage breast tissue density for digital mammography, digital breast tomosynthesis, and magnetic resonance imaging. Breast Cancer Res Treat. 2013;138:311-7. 
104. Tagliafico A, Tagliafico G, Astengo D, Cavagnetto F, Rosasco R, Rescinito G, et al. Mammographic density estimation: one-to-one comparison of digital mammography and digital breast tomosynthesis using fully automated software. Eur Radiol. 2012;22:1265-70.

105. Tagliafico A, Tagliafico G, Tosto S, Chiesa F, Martinoli C, Derchi LE, et al. Mammographic density estimation: comparison among BI-RADS categories, a semi-automated software and a fully automated one. Breast. 2009;18:35-40.

106. Tagliafico AS, Tagliafico G, Cavagnetto F, Calabrese M, Houssami N. Estimation of percentage breast tissue density: comparison between digital mammography (2D full field digital mammography) and digital breast tomosynthesis according to different BI-RADS categories. $\mathrm{Br} \mathbf{J}$ Radiol. 2013;86:20130255.

107. Couwenberg AM, Verkooijen HM, Li J, Pijnappel RM, Charaghvandi KR, Hartman M, et al. Assessment of a fully automated, high-throughput mammographic density measurement tool for use with processed digital mammograms. Cancer Causes Control. 2014;25:1037-43.

108. Sovio U, Li J, Aitken Z, Humphreys K, Czene K, Moss S, et al. Comparison of fully and semiautomated area-based methods for measuring mammographic density and predicting breast cancer risk. Br J Cancer. 2014;110:1908-16.

109. Bakic PR, Carton AK, Kontos D, Zhang C, Troxel AB, Maidment AD. Breast percent density: estimation on digital mammograms and central tomosynthesis projections. Radiology. 2009;252:40-9.

110. Yaffe MJ. Mammographic density. Measurement of mammographic density. Breast Cancer Res. 2008;10:209.

111. Diffey J, Berks M, Hufton A, Chung C, Verow R, Morrison J, et al. A stepwedge-based method for measuring breast density: observer variability and comparison with human reading. In: Samei E, Pelc NJ, editors. Medical Imaging 2010: Physics of Medical Imaging. Bellingham: Spie-Int Soc Optical Engineering; 2010.

112. Kontos D, Bakic PR, Acciavatti RJ, Conant EF, Maidment ADA, (Eds): JMea. A comparative study of volumetric and area-based breast density estimation in digital mammography: Results from a screening population. Girona, Catalonia2010. p. 378-85.

113. Kallenberg MGJ, Lokate M, van Gils CH, Karssemeijer N. Automatic breast density segmentation: an integration of different approaches. Physics in Medicine and Biology. 2011;56:2715-29.

114. Conant EF, Li D, Gavenonis S, Bakic PR, Carton AK, Zhang CP, et al. A Comparative Study of the Inter-reader Variability of Breast Percent Density Estimation in Digital Mammography: Potential Effect of Reader's Training and Clinical Experience. In: Marti J, Oliver A, Freixenet J, Marti R, editors. Digital Mammography. Berlin: Springer-Verlag Berlin; 2010. p. 114-20.

115. Kopans DB. Basic physics and doubts about relationship between mammographically determined tissue density and breast cancer risk. Radiology. 2008;246:348-53.

116. Ren BR, Smith A, Jing ZX. Measurement of breast density with digital breast tomosynthesis. In: Pelc NJ, Nishikawa RM, Whiting BR, editors. Medical Imaging 2012: Physics of Medical Imaging. Bellingham: Spie-Int Soc Optical Engineering; 2012.

117. Wang J, Azziz A, Fan B, Malkov S, Klifa C, Newitt D, et al. Agreement of mammographic measures of volumetric breast density to MRI. PLoS One. 2013;8:e81653.

118. Alonzo-Proulx O, Mawdsley GE, Patrie JT, Yaffe MJ, Harvey JA. Reliability of Automated Breast Density Measurements. Radiology. 2015:141686.

119. Singh JM, Fallenberg EM, Diekmann F, Renz DM, Witlandt R, Bick U, et al. Volumetric Breast Density Assessment: Reproducibility in Serial Examinations and Comparison with Visual Assessment. Fortschritte auf dem Gebiet der Röntgenstrahlen und der bildgebenden Verfahren. 2013.

120. Engelken F, Singh JM, Fallenberg EM, Bick U, Bottcher J, Renz DM. Volumetric breast composition analysis: reproducibility of breast percent density and fibroglandular tissue volume measurements in serial mammograms. Acta Radiol. 2014;55:32-8.

121. Ciatto S, Bernardi D, Calabrese M, Durando M, Gentilini MA, Mariscotti G, et al. A first evaluation of breast radiological density assessment by QUANTRA software as compared to visual classification. Breast. 2012;21:503-6.

122. Regini E, Mariscotti G, Durando M, Ghione G, Luparia A, Campanino PP, et al. Radiological assessment of breast density by visual classification (BI-RADS) compared to automated volumetric digital software (Quantra): implications for clinical practice. La Radiologia medica. 2014. 
123. Gubern-Merida A, Kallenberg M, Platel B, Mann RM, Marti R, Karssemeijer N. Volumetric breast density estimation from full-field digital mammograms: a validation study. PLoS One. 2014;9:e85952.

124. Seo JM, Ko ES, Han BK, Ko EY, Shin JH, Hahn SY. Automated volumetric breast density estimation: a comparison with visual assessment. Clin Radiol. 2013;68:690-5.

125. Lee HN, Sohn YM, Han KH. Comparison of mammographic density estimation by Volpara software with radiologists' visual assessment: analysis of clinical-radiologic factors affecting discrepancy between them. Acta Radiol. 2014.

126. Gweon HM, Youk JH, Kim JA, Son EJ. Radiologist Assessment of Breast Density by BIRADS Categories Versus Fully Automated Volumetric Assessment. AJR Am J Roentgenol. 2013;201:692-7.

127. Cappello NM. Decade of 'normal' mammography reports--the happygram. Journal of the American College of Radiology : JACR. 2013;10:903-8.

128. Price ER HJ, Lipson JA et al. The Carlifonia breast density information group: a collaborative response to the issue of breast density, breast cancer risk, and breast density notification legislation. Radiology. 2013.

129. van Gils $\mathrm{CH}$. Effect of volumetric mammographic density on performance of a breast cancer screening program using full-field digital mammography. European Congress of Radiology. Austria Vienna2015. p. C-0360.

130. Mawdsley GE, Tyson AH, Peressotti CL, Jong RA, Yaffe MJ. Accurate estimation of compressed breast thickness in mammography. Med Phys. 2009;36:577-86.

131. Tyson AH, Mawdsley GE, Yaffe MJ. Measurement of compressed breast thickness by optical stereoscopic photogrammetry. Med Phys. 2009;36:569-76.

132. Malkov S, Wang J, Kerlikowske K, Cummings SR, Shepherd JA. Single x-ray absorptiometry method for the quantitative mammographic measure of fibroglandular tissue volume. Med Phys. 2009;36:5525-36.

133. Heine JJ, Cao K, Thomas JA. Effective radiation attenuation calibration for breast density: compression thickness influences and correction. Biomedical engineering online. 2010;9:73.

134. Kallenberg MG, van Gils CH, Lokate M, den Heeten GJ, Karssemeijer N. Effect of compression paddle tilt correction on volumetric breast density estimation. Phys Med Biol. 2012;57:5155-68.

135. Morrish OW, Tucker L, Black R, Willsher P, Duffy SW, Gilbert FJ. Mammographic breast density: comparison of methods for quantitative evaluation. Radiology. 2015;275:356-65.

136. Mainprize JG, Tyson AH, Yaffe MJ. The relationship between anatomic noise and volumetric breast density for digital mammography. Med Phys. 2012;39:4660-8.

137. Heine JJ, Cao K, Beam C. Cumulative sum quality control for calibrated breast density measurements. Med Phys. 2009;36:5380-90.

138. Jing H, Keller B, Choi JY, Crescenzi R, Conant E, Maidment A, et al. Dependence of radiation dose on area and volumetric mammographic breast density estimation. Lake Buena Vista, FL2013.

139. Pinsky RW, Helvie MA. Mammographic breast density: effect on imaging and breast cancer risk. Journal of the National Comprehensive Cancer Network : JNCCN. 2010;8:1157-64; quiz 65.

140. Buchberger W, Niehoff A, Obrist P, DeKoekkoek-Doll P, Dunser M. Clinically and mammographically occult breast lesions: detection and classification with high-resolution sonography. Semin Ultrasound CT MR. 2000;21:325-36.

141. Crystal P, Strano SD, Shcharynski S, Koretz MJ. Using sonography to screen women with mammographically dense breasts. AJR Am J Roentgenol. 2003;181:177-82.

142. Gordon PB, Goldenberg SL. Malignant breast masses detected only by ultrasound. A retrospective review. Cancer. 1995;76:626-30.

143. Kaplan SS. Clinical utility of bilateral whole-breast US in the evaluation of women with dense breast tissue. Radiology. 2001;221:641-9.

144. Kolb TM, Lichy J, Newhouse JH. Occult cancer in women with dense breasts: detection with screening US--diagnostic yield and tumor characteristics. Radiology. 1998;207:191-9.

145. Leconte I, Feger C, Galant C, Berliere M, Berg BV, D'Hoore W, et al. Mammography and subsequent whole-breast sonography of nonpalpable breast cancers: the importance of radiologic breast density. AJR Am J Roentgenol. 2003;180:1675-9. 
146. Corsetti V, Ferrari A, Ghirardi M, Bergonzini R, Bellarosa S, Angelini O, et al. Role of ultrasonography in detecting mammographically occult breast carcinoma in women with dense breasts. La Radiologia medica. 2006;111:440-8.

147. Destounis SV, Morgan R, Arieno A. Screening for dense breasts: digital breast tomosynthesis. AJR Am J Roentgenol. 2015;204:261-4.

148. Niklason LT, Christian BT, Niklason LE, Kopans DB, Castleberry DE, Opsahl-Ong BH, et al. Digital tomosynthesis in breast imaging. Radiology. 1997;205:399-406.

149. Andersson I, Ikeda DM, Zackrisson S, Ruschin M, Svahn T, Timberg P, et al. Breast tomosynthesis and digital mammography: a comparison of breast cancer visibility and BIRADS classification in a population of cancers with subtle mammographic findings. Eur Radiol. 2008;18:2817-25.

150. Poplack SP, Tosteson TD, Kogel CA, Nagy HM. Digital breast tomosynthesis: initial experience in 98 women with abnormal digital screening mammography. AJR Am J Roentgenol. 2007;189:616-23.

151. Svahn TM, Chakraborty DP, Ikeda D, Zackrisson S, Do Y, Mattsson S, et al. Breast tomosynthesis and digital mammography: a comparison of diagnostic accuracy. $\mathrm{Br} \mathrm{J}$ Radiol. 2012;85:e1074-82.

152. Christopher E. Tromans RH, Oliver Morrish, Richard Black, Lorraine Tucker, Fiona Gilbert, Sir Michael Brady. Patient Specific Dose Calculation Using Volumetric Breast Density for Mammography and Tomosynthesis. Breast Imaging. Switzerland: Springer International Publishing; 2014. p. 158-65.

153. Rhodes DJ, Hruska CB, Conners AL, Tortorelli CL, Maxwell RW, Jones KN, et al. Journal club: molecular breast imaging at reduced radiation dose for supplemental screening in mammographically dense breasts. AJR Am J Roentgenol. 2015;204:241-51.

154. Holbrook A, Newel MS. Alternative screening for women with dense breasts: breast-specific gamma imaging (molecular breast imaging). AJR Am J Roentgenol. 2015;204:252-6.

155. Sun Y, Wei W, Yang HW, Liu JL. Clinical usefulness of breast-specific gamma imaging as an adjunct modality to mammography for diagnosis of breast cancer: a systemic review and metaanalysis. European journal of nuclear medicine and molecular imaging. 2013;40:450-63.

156. Hendrick RE. Radiation doses and cancer risks from breast imaging studies. Radiology. 2010;257:246-53.

157. Kaiser WA, Zeitler E. MR imaging of the breast: fast imaging sequences with and without GdDTPA. Preliminary observations. Radiology. 1989;170:681-6.

158. Biglia N, Bounous VE, Martincich L, Panuccio E, Liberale V, Ottino L, et al. Role of MRI (magnetic resonance imaging) versus conventional imaging for breast cancer presurgical staging in young women or with dense breast. European journal of surgical oncology : the journal of the European Society of Surgical Oncology and the British Association of Surgical Oncology. 2011;37:199-204.

159. Kuhl CK, Schrading S, Strobel K, Schild HH, Hilgers RD, Bieling HB. Abbreviated breast magnetic resonance imaging (MRI): first postcontrast subtracted images and maximum-intensity projection-a novel approach to breast cancer screening with MRI. J Clin Oncol. 2014;32:2304-10.

160. Pediconi F, Catalano C, Roselli A, Dominelli V, Cagioli S, Karatasiou A, et al. The challenge of imaging dense breast parenchyma: is magnetic resonance mammography the technique of choice? A comparative study with $\mathrm{x}$-ray mammography and whole-breast ultrasound. Investigative radiology. 2009;44:412-21.

161. Van Goethem M, Schelfout K, Dijckmans L, Van Der Auwera JC, Weyler J, Verslegers I, et al. MR mammography in the pre-operative staging of breast cancer in patients with dense breast tissue: comparison with mammography and ultrasound. Eur Radiol. 2004;14:809-16.

162. Muuller RD, Barkhausen J, Sauerwein W, Langer R. Assessment of local recurrence after breast-conserving therapy with MRI. J Comput Assist Tomogr. 1998;22:408-12.

163. Mussurakis S, Buckley DL, Bowsley SJ, Carleton PJ, Fox JN, Turnbull LW, et al. Dynamic contrast-enhanced magnetic resonance imaging of the breast combined with pharmacokinetic analysis of gadolinium-DTPA uptake in the diagnosis of local recurrence of early stage breast carcinoma. Investigative radiology. 1995;30:650-62. 
164. Murray AD, Redpath TW, Needham G, Gilbert FJ, Brookes JA, Eremin O. Dynamic magnetic resonance mammography of both breasts following local excision and radiotherapy for breast carcinoma. Br J Radiol. 1996;69:594-600.

165. Lee CH, Dershaw DD, Kopans D, Evans P, Monsees B, Monticciolo D, et al. Breast cancer screening with imaging: recommendations from the Society of Breast Imaging and the ACR on the use of mammography, breast MRI, breast ultrasound, and other technologies for the detection of clinically occult breast cancer. Journal of the American College of Radiology : JACR. 2010;7:18-27. 